INTERNATIONAL JOURNAL OF MULTIDisciplinARY RESEARCH AND ANALySis

ISSN(print): 2643-9840, ISSN(online): 2643-9875

Volume 04 Issue 01 January 2021

DOI: 10.47191/ijmra/v4-i1-14, Impact Factor: 6.072

Page No.- $95-100$

\title{
Appraisals of the Socio- Economic Characteristics of Waste scavengers in Mubi Metropolis, Nigeria
}

\author{
Ezekiel John Gangaya ${ }^{1}$, Alfred D. Mshelia ${ }^{2}$ \\ ${ }^{1}$ Vimtim Central Primary School, Mubi North Local Government Area Adamawa State, Nigeria. \\ ${ }^{2}$ Department of Geogrphy, Adamawa State University, Mubi, Nigeria
}

\begin{abstract}
The study examines the socio-economic and demographic characteristics of waste scavengers, practitioners of a common form of solid waste resource recovery practices in Mubi metropolis. A total number of two hundred sets of questionnaire were administered to waste scavengers and eight waste merchants out of which 176 sets of the questionnaire were retrieved and analysed. The purposive and Snowball Sampling Techniques were employed to identify the respondents. Tables, percentage Charts, point bisereal correlation, t-test and one way ANOVA technique were used for the analysis. The results revealed that majority of the scavengers within Mubi metropolis are male (93.2\%). The female counterparts do not partake much in these types of trade. The reason could not be far fetched from the unwholesome nature of the business and its demands. Generally, the educational status of respondents' shows that majority of practitioners $44.3 \%$ pass through formal education or may not have attended any school system. This attest to the fact that they may not be knowledgeable with regard to the rudiment of resource recycling or reuse. Further result revealed that practitioners were overwhelmingly pushed into scavenging business (93.8\%) by poverty/unemployment. Be as it may, all (100\%) scavengers revealed that scavenging has increased their income and consequently their standard of living. The Pearson's point-biserial correlation coefficient shows a very weak negative linear relationship between both variables of income and impact of scavenging on health of scavengers. $\left(r_{p b}=-0.071, n=176, p=3, A t\right.$ $p>0.05$ ) This relationship goes to show that there is no significant relationship between monthly income and impact (positive and negative) of scavenging on health of Merchants and scavengers in Mubi metropolitan area of Adamawa State. Conclusively, scavenging practice plays a greater role in poverty alleviation and creation of employment especially among those categories of scavengers that attended informal education or not any other school system. However, most scavengers (61.4\%) affairs to be urgent need of capital to sustain and boost their businesse.
\end{abstract}

\section{INTRODUCTION}

In general, waste is unwanted materials for the person who discards it; a material that does not have a value or has lost its value for the first user and is therefore thrown away or discarded (Afons 2013). In the context of Integrated Solid Waste Management (ISWM), waste is regarded as valueless, useless and as a useful material providing an important source of income to some people. This real value of waste in many low-and middle-income countries (developing countries) is confirmed by the huge informal sector that lives on waste collection and recovery (Van de Klundert and Justine, 2001).

Due to social and environmental consequences, waste reuse, recycle and recovery have become essentials in minimizing the environmental damage that could occur through indiscriminate waste disposal (Sivapalan, Mohamad, and Muhd-Noor, 2005). Davies (2008) notes that what some people consider to be waste materials or substances are considered a source of value or source of income to some people. This relative attribute of waste can be compared with the concept of resource which has also been defined as material that has use-value and a reflection of human appraisal (Jones and Hollier, 1977). Just as a material becomes a resource when it gains use-value, it also becomes waste when it loses its use-value. Like resources, waste is also a relative concept of human appraisal because what constitutes waste can vary from one person to another, one society to another and over time. As noted by (Jessen, 2002) our waste stream is actually full of resources going in the wrong direction. Waste reuse and recovery as an alternative management option for waste is now recognized as a crucial method for solving waste problem both in developed and developing world. 


\section{Appraisals of the Socio- Economic Characteristics of Waste scavengers in Mubi Metropolis, Nigeria}

Resource recovery from dumped consumer products is growing in significance, as waste is increasingly seen as a valuable resource. As human beings continuously realized that resources are finite, efficient use of resources and resources recovery from wastes are vital for global environmental sustainability (Zaman and Lehmann, 2011). Developed countries generally rely on land filling to overcome the problem of waste accumulation (Girling, 2005; Pacione, 2005). The landfill seems to have a special attraction for municipal waste managers because it offers a cheap and convenient option for waste disposal compared with other strategies such as reuse, and energy recovery (Charzan, 2002). In fact, with the exception of few countries like Austria, the Netherlands and Denmark who recycle substantial proportions of their waste, most countries in Europe and North America still dump the bulk of their municipal solid waste in landfills (OECD, 2002; Girling, 2005).

A waste scavenger is a person who salvages reusable or recovery materials to sell or for personal consumption (Hari, 2011). Scavenging from the waste stream is an important economic activity that provides income for over 15 million people worldwide, most of whom are in cities in developing countries, and it has a financial impact of several billions of US- dollars every year (Medina, 2010). Scavenging has become a major feature of waste management in many cities in third world countries. Scavenging is now regarded as a means to reduce the amount of solid waste to be disposed and help to save and conserved the natural resources that lead to sustainable development (Muktar, 2011). It creates jobs and extra income for people especially the poor. Scavenging makes people to sort out materials from wastes in exchange for money and supplies raw materials for recycling enterprises. Nigerian Environmental Study Action Team (NEST) (1991) revealed that; harsh economic condition in the country has led to the emergence of interest in waste recovery. Where it has become common to see scavengers at work on most waste disposal sites salvaging all items they believe to be salvageable, usable as they are or in demand as industrial raw materials. Examples include; unbroken bottles, rusty pots and pans, broken metal chair legs, leaking plastic containers, old car tyres and plastic shoes, clothes, buttons, and zip fasteners, as well as milk tins, among others. Despite the obvious health hazards which scavenging poses to both the scavengers and their customers, it must be admitted that it is helping the society to cope with solid waste disposal problem. This goes to say that if what constitute our waste is segregated and their uses found, they can be good sources of raw materials for our cottage industries, generate employment and income, and equally rid our cities of refuse dumps or reduce our waste stream destined for the healthy environment, Mshelia, ( 2015 ).

According to Solomon, (2009), in his study on the state of solid waste management in Nigeria; it is estimated that an average Nigerian generates about $0.49 \mathrm{~kg}$ of solid waste per day with households and commercial centres contributing almost $90 \%$ of total urban waste burden. Little information exists on industrial, agricultural and biomedical waste profiles. As with most developing countries, a greater percentage of solid waste composed of organic matter, but recently there has been a marked increase in the amount of plastic wastes generated in Nigeria (Solomon 2009). Adeyemi et. al., (2001) examined the role of waste scavengers in the waste recovery process in Mubi, Nigeria. Using plastic waste as an example, it was demonstrated that such recycling is economically viable. At the backdrop, the study examine the socio economic and demographic characteristics of those achieving a driving source of livelihood through resource recovery from waste generated and disposed in Mubi Metropolis, Nigeria.

\section{METHODOLOGY}

A set of questionnaires was used to collect data for this study. Data on the socio economic and demographic characteristics of scavengers in the study area was summarised inform of a table of frequency and percentages. The Non-probability sampling techniques, purposive and snowball sampling technique were used in locating recyclable materials collection depots and identifying respondents (practitioners) for questionnaire administration. The selected localities where recyclable materials collection depots were identified include: Kabang Junction, Arahankunu, Yelwa, Saibore, Kolere, Wuro-gude, Wuro -Kwandon, and Wuro-Patuje depots. Consequently, 200 respondents were selected purposively for questionnaire administration. Where one hundred and seventy six scavengers were able to fill and return the sets of questionnaire issued to them.

Inferential statistical test using the statistical Package for Social Sciences (SPSS) Version 23 was used to analyze the data collected from one hundred and seventy six scavengers. Data collected were analyses using one way analysis of variance (ANOVA), pointsbiserial correlation and in depended sample t-test statistics at 0.05 .

\section{Socio-Economic and Demographic Characteristics of Respondents.}

Data collected on socio-economic and demographic characteristics of the respondents is summarised in table 1 . The classification of scavengers by wards indicates most scavengers $28.4 \%$ reside in Yelwa ward, while $15.3 \%$ of respondent are based in Kolere ward. $13.6 \%$ of the scavengers also reside in Sabon layi, while $11.9 \%$ are located in Lamurde whereas $5.1 \%$ and $4.0 \%$ are based in Gude and Digil wards respectively. The fore going youthfull analysis indicate that majority of waste resource recovery practitioners are Yelwa ward residents. 


\section{Appraisals of the Socio- Economic Characteristics of Waste scavengers in Mubi Metropolis, Nigeria}

Classification of the scavengers by age demonstrated that majority $49.4 \%$ fall within the age bracket of $15-20$ years, $27.3 \%$ are between 36 years and above. While $23.3 \%$ fall within the age bracket of $26-35$ years. Age in any form of economic endeavour is synonymously with productivity. Hence a youth full age bracket shows a high potential for high productivity with regard, to scavenging practice because bulk of' practitioners are of the vibrant school gone age. To this regard it is expected to see a commensurate of energy channelled by the youth to mass recovery of resources from waste. Further analysis based on data presented in table 1 revealed that most of the respondents (93.2\%) are male while the remaining (6.8\%) were female, depicting that the scavenging profession is male dominated, while the low female participation could not be farfetched from the nature of the business and its demands. Excessive energy with regard, to traversing through nooks crannies picking reusable or recyclable materials on commercial basis. Educationally, data summarised shows the status of scavengers (44.3\%) went through informal education while $44.3 \%$ are illiterates. Twenty nine per cent of scavengers possess WAEC/GCE and (22.7\%) have first school leaving certificate. The remaining 3.4\% have diploma and only 1 has HND/Degree. It is evidence from the analysis that most scavengers went through informal education or may not have attended any school system at all. This will not be farfetched to say that the low level of education of scavengers attest to the low social status of the practitioners, beside, the knowledge with regards to recycling know how the material collected may be absent and that is why they resort to only selling their collection to merchant for paltry sums, which are subsequently packaged and transported by trucks to recycling enterprises for better profit. Be site the low literacy level affect the ability of scavengers to know the true value of their collection, hence affecting their level of income (remunerations) while the middle men (merchants) and recycling enterprises, are in to lucrative business. Most scavengers (55.7\%) engaged in full time scavenging, while $44.3 \%$ are in to scavenging as part time, implying that it is not their primary business, they have other sources of income $57.7 \%$ are farmers. $24.4 \%$ are petty traders while $17.9 \%$ are in to other material jobs. One could infer from this position that since farming is a seasonal employment, those engage in to farming resort to scavenging during off farming season (dry season). While overwhelming percentage factor that pushed (93.8\%) of scavengers, took to the scavenging business due to poverty/ unemployment $6.3 \%$ were in to scavenging for different reasons, particularly by inheritance or family business. Consequently, were affirmative that scavenging scavenging from waste dumps helped in their increased income, which improved their standard of living, as they boast of purchasing livelihood items ( television, DVD sets, radio, couches bedding material payment of house rent, marriage, acquire plots of land, pay school fees, medical bill and personal effects (clothing, foot ware) etc.

Table 1. Socio-Economic and Demographic Characteristics of Respondents

\begin{tabular}{lll}
\hline Items & Frequency & Percentage (\%) \\
\hline Respondents Ward & & \\
Lokuwa Ward & 18 & 10.2 \\
Digil Ward & 7 & 4.0 \\
Yelwa Ward & 50 & 28.4 \\
Sabon Layi Ward & 24 & 13.6 \\
Kolere Ward & 27 & 15.3 \\
Nasarawo Ward & 20 & 11.4 \\
Gude Ward & 9 & 5.1 \\
Lamurde Ward & 21 & 11.9 \\
Total & 176 & 100.0 \\
Age of Respondents & & \\
15 - 25 Years & 87 & 49.4 \\
26- 35 Years & 41 & 23.3 \\
36 and Above Years & 48 & 27.3 \\
Total & 176 & 100.0 \\
Sex of Respondents & & \\
Male & 164 & 93.2 \\
Female & 12 & 6.8 \\
Total & 176 & 100.0 \\
Educational Qualification & & \\
of Respondent & 40 & \\
First School Leaving Cert. & & \\
& &
\end{tabular}


Appraisals of the Socio- Economic Characteristics of Waste scavengers in Mubi Metropolis, Nigeria

\begin{tabular}{lll} 
WAEC/GCE & 51 & 29.0 \\
Diploma & 6 & 3.4 \\
HND/Degree & 1 & .6 \\
Others & 78 & 44.3 \\
Total & 176 & 100.0 \\
Status of Job & & \\
Full Time & 98 & 55.7 \\
Part Time & 78 & 44.3 \\
Total & 176 & 100.0 \\
Part Time Jobs & & \\
Farming & 45 & 57.7 \\
Petty Trade & 19 & 24.4 \\
Others & 14 & 17.9 \\
Push for scavenging & & \\
Yes & 165 & 93.8 \\
No & 11 & 6.3 \\
Total & 176 & 100.0 \\
Increased Income & & \\
from Scavenging & & \\
Yes & 176 & 100.0 \\
No & 0 & \\
Total & 176 & $\mathbf{1 0 0 . 0}$ \\
\hline
\end{tabular}

\section{RESEARCH HYPOTHESIS}

Hypothesis 1

A hypothesis sought to determine if there is a significant difference in the mean monthly income of Scavengers in Mubi based on gender. The monthly income of the scavengers based on gender was obtained and the t-Test was used to analyse the data. The observable result as presented in Table 2 shows that there is no significant difference in the mean monthly Income of scavengers based on gender. This result shows that male and female scavengers did not differ significantly in their monthly income in Mubi metropolis of Adamawa State which justifies the fact that income is not a function of gender but others factors such as environmental conditions and micro economic variables that have significant influence on the level of income.

Table 2. Summary of t-Test Analysis of Scavengers' Monthly Income Based on Gender

\begin{tabular}{llllllll}
\hline Source & $\mathbf{N}$ & Mean & $\begin{array}{l}\text { Mean } \\
\text { Difference }\end{array}$ & SD & Df & t & Sig. (2-tailed) \\
\hline Male & 164 & $25,701.22$ & & $17,552.70$ & & & \\
& & & -7048.78 & & 174 & -0.134 & .181
\end{tabular}

Not Significant; $p>0.05$

Source: Researcher field studies 2017.

To test the hypothesis, regarding the scavengers mean' monthly income base on age group using One Way Analysis of Variance (ANOVA). Scavengers in the age bracket of 26-35 years gained the highest monthly mean income of N28, 609.76 compared to their counterpart in age bracket 36 years and above with mean income of N28, 020.83. Scavengers that fall within the age bracket of 15 - 25 year have a Mean income of N24, 022.99. To determine if these mean incomes were significantly different, the oneway ANOVA was applied. The result summarized in Table 3 shows that there is no significant difference in the mean income of scavengers based on their age groups. This implies that the monthly income of scavengers and merchants based on age groups does not differ. 
Appraisals of the Socio- Economic Characteristics of Waste scavengers in Mubi Metropolis, Nigeria

Table 3. Summary of One Way Analysis of Variance (ANOVA) of Scavengers' Monthly Income based their Age Groups

\begin{tabular}{lrllll}
\hline Source of Variation & Sum of Squares & df & Mean Square & F & Sig. (2-tailed) \\
\hline Between Groups & 809492530.97 & 2 & 404746265.483 & & .273 \\
Within Groups & 53454189287.22 & 173 & 308983753.105 & 1.310 &. \\
Total & 54263681818.18 & 175 & & & \\
\hline
\end{tabular}

Significant; $p>0.05$.

To test the third hypothesis, which states there is no significant relationship between monthly income and gender (male and female) of merchant and scavengers in mubi metropolis, the mean scores of their perceived response obtained from the instrument were analyzed.

A Summary of the mean scores of the perceived relationship between monthly income and Gender (Male and Female) of Merchants and scavengers. Shows that monthly income has the highest mean values (Mean $=26181.82$ ) and gender also has (Mean =1.07). Hence, to obtain the extent of relationship between the variables, the point-biserial correlation was used and the result provided in Table 4.

Shows there is no significant linear relationship between the perceived monthly income and Gender (Male and Female) of Merchants and scavengers in Mubi metropolis. Pearson's biserial correlation coefficient shows a very weak positive linear relationship between both test scores, means that there is no significant relationship between monthly income and Gender (Male and Female) of Merchants and scavengers in Mubi metropolitan area of Adamawa State.

Table 4. Summary of Point-Biserial Correlation between the Perceived Response on Gender and Monthly Income.

\begin{tabular}{ll}
\hline Source & Statistics \\
\hline Pearson Correlation & 0.10 \\
Significant(2-tailed) & 0.18 \\
$\mathbf{N}$ & 176 \\
\hline
\end{tabular}

Correlation is not significant at the 0.05 level (2-tailed).

\section{CONCLUSION}

The inability of scavengers to appreciate and imbibe the sprite of recycling and reuse is far fetched because they were drawn into the profession not based on passion and knowledge of waste reuse and recycling but circumstance surrounding their joblessness. Be a it may, the practice of scavenging has played a great role in the life of practitioners, as it provides them with the job that helps lower their level of poverty.

\section{RECOMMENDATIONS}

The study therefore goes to recommend that;

i. Adult education and formal schools be established by government and non-governmental organization to educate scavengers since most of them are illiterates and that could be the reason for their unemployment, education will equally broaden their understanding on recycling and reuse of resource recovered.

ii. The establishments of waste recycling enterprises in the area to enhance the income of scavengers, and hence the economy of the region or at least semi- process them to enhance better income and benefits accruable from resource recovery.

iii. iii. Scavengers and junk merchants alike need to acquire the ability of recycling their collection by themselves to increase their income.

\section{REFERENCES}

1) Afon, A.O. (2003). Issues in Urban Residential Area Solid Waste Management Sustainability: Challenges of Environmental Sustainability in a Democratic Government. Proceedings of 11th National Conference of the Environment and Behaviour Association of Nigeria held in Akure, Nigeria, 23rd - 25th Oct 2003. Akron

2) Anthony, B. (2009) Urban Environmental Problem in Ghana; a Case Study of Social and Environmental Injustice in Solid Waste Management in Accra and Sekondi-Takoradi: Norway, NTUN. 


\section{Appraisals of the Socio- Economic Characteristics of Waste scavengers in Mubi Metropolis, Nigeria}

3) Adeyemi, A. S. Olorunfemi, J.F and Adewoye, T.O. (2001) Waste Scavenging in Third World Cities: case Study Ilorin, Nigeria. The Environmentalist, 21 (2): 93-96.

4) Charzan, D. (2002). A world Drawing in Litter, BBC full Tex Data Base. BBC. News Online, Accessed from http://news.bbc.co.uk/i/hi/worl/europe/1849302 stm on 12/05/08.

5) Davies, A.R. (2008). The Geographies of Garbage Governance: Interventions. Interactions and Outcomes. London: Ashgate.

6) Girling, R. (2005). Publish Dirt on our Hand and Cries Ahead. London Eden Project Books, Tran world Publishing Ltd.

7) Jessen, M. (2002). Zero Waste Services. Assessed from: http:/www.zerowaste.ca/articles html. On 21/06/2007).

8) Jones, G., and Holier, G. (1977). Resources, Society and Environmental Management. London: Paid Chap Man Publishing Limited.

9) Medina,M.(2010),Scrap and Trade; Scavenging Myths National Oceanic a Atmospheric Administration. The Canadian Geography 45, 3:387-403.

10) Muktar, M. (2011). The Economics of Waste Scavenging in Kano State Department of Economics Bayero University, Kano, Nigeria. Pg. 4-5.

11) Mshelia, A. D. (2015). Municipal solid waste scavenging practice's in Mubi, Nigeria. Sky Journal of Soil Science and Environmental Management Vol. 4(4), pp. 040 - 045, July, 2015 Available online http://www.skyjournals.org/SJSSEMISSN 2315-8794@ 2015 Sky Journals Review Paper

12) Nigerian Environmental Study Action Team, Nest. (1991). Nigeria's Threatened Environment: a National Profile. Ibadan: Nigeria Environmental Study/Action Team Ibadan. Nigeria pg. 239-240.

13) OECD, (2002). Environmental Performance Review (1st Cycle). Conclusions and Recommendations. 32 Countries. Ireland. Accessed from: http://www.oecd.org/dataoecd/19/56/2432829.pdf on 04/02/07.

14) Pacione, M. (2005). Ulrban Geography. A Global Perspective, $2^{\text {nd }}$. Edition, London and New York Rout Edge, Taylor and Frances Group.

15) Sivapalan, K. Mohamad, A. C.M.I. Mohamad, P. A. and Muhd Noor, M.Y. (2005). Waste to Wealth. MINT Incineration and Renewable Centre (MIREC), Malaysian Institute of Nuclear Technology (MINT), Bangi, 43000, Kajang. Skinner,

16) Solomon U.U (2009). He State of Solid Waste Management in Nigeria. Wulan, Hunan, Hubei: Department of Environmental Engineering, Chin University of Geoneer, Wuhan, Hubei.

17) Tashakkori, A., Teddlie, C.(2003a). Handbook of Mixed Method in Social and Behavioral Research Thausand Daks, Sage. pp. 671702.

18) Van de Klundert, A. and Justine, A. (2001). Integrated Sustainable Waste Management. Waste, Gouda: Netherlands. www.Waste.

19) Zaman, A.U. and Lehmann, S. (2011). Zero Waste City. Zero Waste South Australia Research Centre for Sustainable Design and Behaviour; School of Art, Architecture and Design, University of South Australia. Pp. 14-15. 